\title{
Entrepreneurship Determines Public Empowerment through Good Governance and Public Service Quality
}

\author{
Rojikinnor ROJIKINNOR ${ }^{1}$, A. Juli Andi GANI ${ }^{2}$, Choirul SALEH ${ }^{3}$, Fadillah AMIN ${ }^{4}$ \\ Received: July 03, 2020 Revised: September 19, 2020 Accepted: October 05, 2020
}

\begin{abstract}
This study examines the relationship between entrepreneurship of the state civil apparatus variable and public empowerment variable in Central Kalimantan province. Samples were taken using judgment sampling techniques. Based on these criteria, it is known that only 332 regional organizational structures that meet the criteria. Thus, the sample size is 332 regional organizational structure. In each organizational structure of the regional apparatus, 3 people were selected from the state civil apparatus and 3 from the community. Also, this study considers the effect of good governance and the quality of public services as mediating variables. The analysis used in this study is PLS using WarpPLS software. the variables studied were entrepreneurship of the state civil apparatus, good governance, public service quality and public empowerment. The results of the study stated that there is a significant positive relationship between entrepreneurship and public empowerment. In addition, there is a positive effect of entrepreneurship on good governance and public service quality. also, there is a positive influence of good governance and public service quality on public empowerment. The novelty of this research is the entrepreneurship of the state civil apparatus which is the driving force of public empowerment through good governance and public service quality.
\end{abstract}

Keywords: State Civil Apparatus, Entrepreneurship, Good Governance, Public Service, Public Empowerment

JEL Classification Code: E5, E7, H1, H7, P1

\section{Introduction}

Administration generally related to the formulation of policies in order to achieve organizational goals. Hence administration is important to keep organization sustainability. Public administration is more complex with a bigger scope involving three institutions, that is executive, legislative, and judiciary. Public administration comprise public policies, public management, nation goals, and ethics governing state administrators. In the new Public

${ }^{1}$ First Author and Corresponding Author. Faculty of Administrative Science, Brawijaya University, Indonesia [Postal Address: Veteran Street, Malang, East Java, 65145, Indonesia]

Email: rojikinnor67@student.ub.ac.id

${ }^{2}$ Faculty of Administrative Science, Brawijaya University, Indonesia. Email: andigani@gmail.com

${ }^{3}$ Faculty of Administrative Science, Brawijaya University, Indonesia. Email: choirulsaleh@gmail.com

${ }^{4}$ Faculty of Administrative Science, Brawijaya University, Indonesia

(C) Copyright: The Author(s)

This is an Open Access article distributed under the terms of the Creative Commons Attribution Non-Commercial License (https://creativecommons.org/licenses/by-nc/4.0/) which permits unrestricted non-commercial use, distribution, and reproduction in any medium, provided the original work is properly cited.
Service Paradigm, it is stated that the Government need to assist the community in a democratic, ethical, fair, nonbiased, trustworthy and responsible manner. Consequently, government representatives must handle the citizens as users of public services - not as consumers.

One of the determinants regarding the quality of public services is good governance. Good governance related to control and regulation which points from the mechanism of relations between the various parties that manage the government. In this matter, the state civil apparatus plays an important role. They need to cooperate with numerous other parties, such as the citizens and communities. The state civil apparatus required to be more professional, present services to the community in a reasonable, fair process. They also need to have a global outlook and is expected to be able to proceed to grow by developing their quality and competence.

In associate with that circumstance, entrepreneurship is a necessity for the state civil apparatus. Entrepreneurship is a process of applying creativity and innovation during resolving problems and finding opportunities to improving work life. Previous research conducted by Zampetakis and Moustakis (2010), Bartlett and Dibben (2002), and Sadler (2000) discuss that entrepreneurship affect the state civil apparatus and government. 
Good governance and good public service might drive public empowerment. Empowerment is a popular concept about community development introduced by Friedmann (1992). Chambers (1995) describes that empowerment is marked by people-centred, participatory, empowering and sustainability. Empowerment strategy in community development is an effort which is performed to improve and make the community independent (Somasundram et al., 2017). It is as well as supporting the community in accordance with its potential and local culture in its entirety and comprehensively. Public empowerment is expected to be able to improve the condition of the dignity and layers of society who currently are poverty and underdevelopment. Public empowerment is additionally important to generate a competitive climate for the community to raise the nation's potential.

This research is conducted to investigate furtherly the determinant factors of public empowerment. Public empowerment cannot be separated from the concept of public service. This is confirmed by Wirasari's study (2010) which stated that there is a relation between the quality of public services to public empowerment. Furthermore, Susanto et al. (2015) and Hasan et al. (2017) emphasises that the application of good governance can improve the condition of public services. Public services and good governance are perceived to be affected by entrepreneurship (Yi et al, 2018). This conclusion was taken from Bartlett and Dibben (2002) and Sadler (2010) study who examined entrepreneurship in the public area.

Based on the description above, this study will discuss the determinant factors of community empowerment which include the quality of public services, good governance, and entrepreneurship of the state civil apparatus. The relationship examined in this study covers direct and indirect effect amidst the quality of public services and good governance as a mediating variable. Based on previous research, no study comprehensively discusses the relationship between the quality of public services, good governance, and entrepreneurship towards public empowerment has been found.

This study conducted in Central Kalimantan Province in Indonesia. It is one of the provinces located on the island of Kalimantan. The capital of the province is Palangkaraya City. Central Kalimantan Province was chosen as research locus because its Provincial Government has released the LAPOR application since October 2018. That LAPOR application was meant to be specifically used to receive aspirations, suggestions, or complaints from the community concerning public services. With this application, it can be said that the Central Kalimantan Provincial Government facilitates community empowerment.

\section{Literature Review and Conceptual Framework}

Entrepreneurship of the State Civil Apparatus. The word entrepreneurship ought a positive meaning with advanced management ideas. Entrepreneurship does not only refer to the entrepreneur spirit, but a term to mention the spirit of anyone who thinks creatively and works innovatively (Suryana 2006). Moreover, Slevin and Covin (1990) stated that entrepreneurship represents a structured behaviour, including risk-taking, proactive and innovative. The core of entrepreneurship is the capacity to produce new and different things through creativity and innovation. People with an entrepreneurial spirit and attitude usually behave confidently, initiative, possess achievement motives (results-oriented and forward-looking), also own leadership (dare to be different), and dare to take risks with considered calculation.

Good Governance. Good governance is a system that has been defined by multiple worldwide institutions. One of the mentioned institutions is the United Nations Development Program (UNDP) in its policy document in 1997 entitled "Governance for Sustainable Human Development". It defines good governance as a synergic and constructive connection between nations, the private sector, and community (Dwiyanto, 2005). Good governance simply is the implementation of trustworthy and responsible development control reciprocal with the principles of democracy and efficient markets. Good governance also avoids misallocation of investment funds and prevention of corruption -both politically and administratively-, leading out budgetary discipline, creating a legal and governmental framework for the completion of activities work.

Public Service Quality. Quality is the standard that must be achieved by a person/ group/ institution/ organization concerning the quality of human resources. Quality can involve either the quality of work methods or quality of products in the form of goods and services (Luc, 2018). Simply, quality determines the satisfaction of those served in the optimal sense of the fulfilment of the demands/ requirements of the customer. Hardiyansyah (2011) suggest that service quality is how a service presented to customers in appropriate the relevant service standards. Quality in public services is a dynamic condition associated with products, services, people, processes, and the environment. Based on those criteria, the best quality of service including serving at all times and done properly, agreeably, politely, friendly, helpful, and professional.

Public Empowerment. In the government, the community is not only as the beneficiary, yet also being agents of development. The community being agents through public empowerment which is people-centred development. Public empowerment involving local resource management, which is a planning mechanism that maintains social learning technology and program formulation strategies. Community empowerment is actually a part of the four functions of government expressed by Rasyid(2000). Those functions namely service (public service), development, empowerment, and regulation. The functions of government that are given out at a certain time will represent the quality of the government itself. If the government conducts out its functions properly, then the main responsibilities can be carried out well i.e. services that achieve justice, empowerment leads to independence, and development that creates prosperity. 


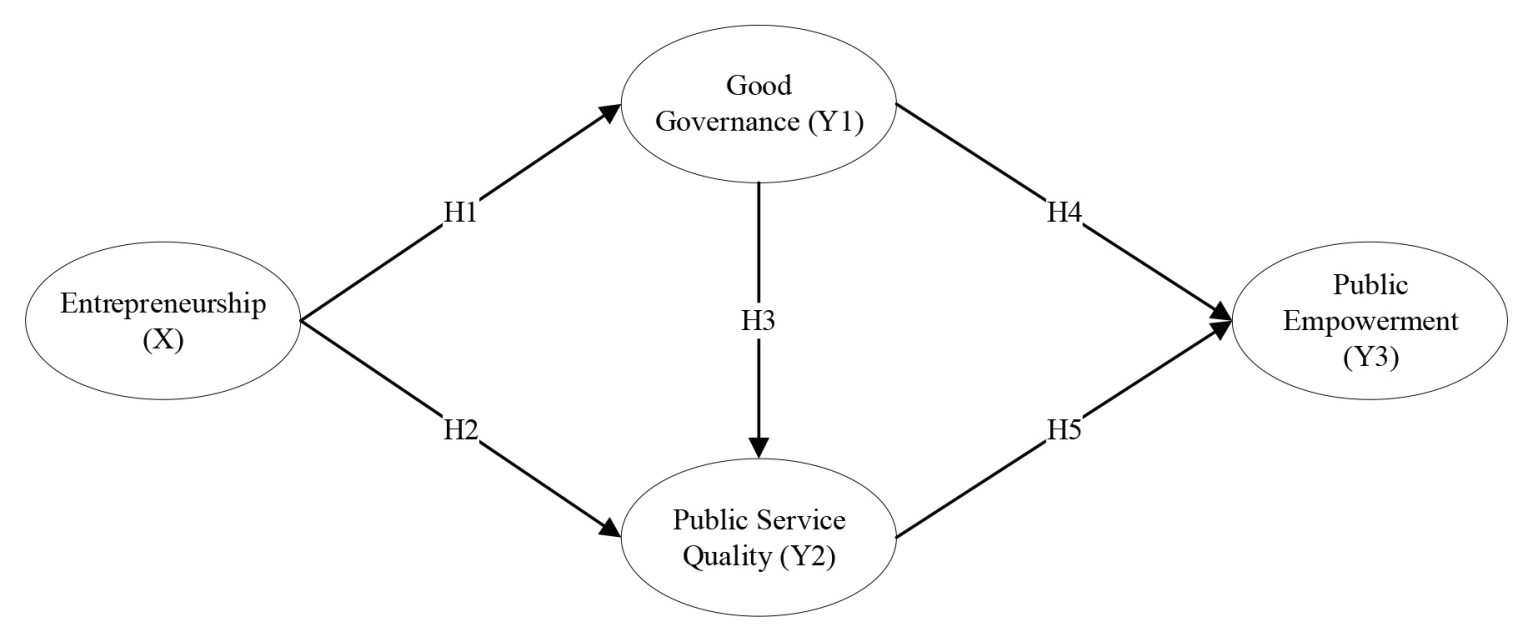

Figure 1: Conceptual Model

This study relating four variables: Entrepreneurship of the State Civil Apparatus, Good Governance, Public Service Quality, and Public Empowerment. Based on the definition of each variable as stated earlier and also past research that had been conducted, this study propose a conceptual framework as Figure 1.

\section{Methodology}

This research uses a quantitative approach and includes explanatory research. The variables used are latent variables, which are variables measured through indicators. The Entrepreneurship and Good Governance variables can only be assessed by the state civil apparatus, while the Public Service Quality and Public Empowerment variables can only be assessed by the community. Thus, the sample unit in this study must include state civil apparatus and society, namely the Organizational Structure of the Regional Apparatus.

Central Kalimantan Province has 430 Organizational Structure of the Regional Apparatus, which consists of offices, civil service police units, and districts. Samples were taken using judgment sampling techniques, with the following conditions.

a) Organizational Structure of the Regional Apparatus that empowers the community

b) Organizational Structure of the Regional Apparatus that provides direct services to the community

Based on these criteria, it is known that only 332 Regional Organizational Structures that meet the criteria. Thus, the sample size is 332 Regional Organizational Structure. In each Organizational Structure of the Regional Apparatus, 3 people were selected from the state civil apparatus and 3 from the community.

\section{Results}

\subsection{Descriptive Statistics}

Descriptive analysis for the variables Entrepreneurship (X), Good Governance (Y1), Public Service Quality (Y2) and Public Empowerment (X3) are presented in Tables 1 through 4. Descriptive analysis in the form of frequency and percentage of answers for each question item. The scale for each question item is a Likert scale. Likert scale is a scale from one to five scale.

\subsubsection{Entrepreneurship (X)}

Entrepreneurship (X) is measured using several indicators. The indicators of the entrepreneurship variable $(\mathrm{X})$ are Strategic Renewal (X.1), Sustained Regeneration (X.2), Domain Redefinition (X.3) Organizational Rejuvination (X.4) and Business Model Reconstruction (X.5). Each indicator is measured using one question item. In full, the frequency and percentage of Entrepreneurship answers (X) can be seen in Table 1 .

\subsubsection{Good Governance (Y1)}

Good Governance (Y1) is measured by several indicators. Indicators of good governance are Transparency (Y1.1), Accountability (Y1.2), Responsibility (Y1.3), Independence (Y1.4) and Fairness (Y1.5). Indicators Transparency (Y1.1), Accountability (Y1.2) and Fairness (Y1.5) are each measured by one question item. Whereas indicators of Responsibility (Y1.3) and Independence (Y1.4) were each measured by two question items. In full, the frequency and percentage of Good Governance (Y1) answers can be seen in Table 2. 
Table 1: Frequency and Percentage of answers from Entrepreneurship $(X)$

\begin{tabular}{|c|c|c|c|c|c|c|c|c|c|}
\hline \multicolumn{2}{|c|}{ X.1 } & \multicolumn{2}{c|}{ X.2 } & \multicolumn{2}{c|}{ X.3 } & \multicolumn{2}{c|}{ X.4 } & \multicolumn{2}{c|}{ X.5 } \\
\hline $\mathbf{f}$ & $\%$ & $\mathbf{f}$ & $\%$ & $\mathbf{f}$ & $\%$ & $\mathbf{f}$ & $\%$ & $\mathbf{f}$ & $\%$ \\
\hline 9 & 0,009 & 13 & 0,013 & 10 & 0,010 & 10 & 0,010 & 12 & 0,012 \\
\hline 161 & 0,162 & 140 & 0,141 & 150 & 0,151 & 123 & 0,123 & 140 & 0,141 \\
\hline 344 & 0,345 & 300 & 0,301 & 307 & 0,308 & 333 & 0,334 & 312 & 0,313 \\
\hline 326 & 0,327 & 368 & 0,369 & 357 & 0,358 & 345 & 0,346 & 350 & 0,351 \\
\hline 156 & 0,157 & 175 & 0,176 & 172 & 0,173 & 185 & 0,186 & 182 & 0,183 \\
\hline
\end{tabular}

Table 2: Frequency and Percentage of answers from Good Governance (Y1)

\begin{tabular}{|c|c|c|c|c|c|c|c|c|c|c|c|c|c|}
\hline \multicolumn{2}{|c|}{ Y1.1.1 } & \multicolumn{2}{|c|}{ Y1.2.1 } & \multicolumn{2}{|c|}{ Y1.3.1 } & \multicolumn{2}{|c|}{ Y1.3.2 } & \multicolumn{2}{|c|}{ Y1.4.1 } & \multicolumn{2}{|c|}{ Y1.4.2 } & \multicolumn{2}{|c|}{ Y1.5.1 } \\
\hline$f$ & $\%$ & $f$ & $\%$ & f & $\%$ & $f$ & $\%$ & $F$ & $\%$ & $f$ & $\%$ & $f$ & $\%$ \\
\hline 17 & 0,017 & 10 & 0,010 & 12 & 0,012 & 16 & 0,016 & 10 & 0,010 & 6 & 0,006 & 10 & 0,010 \\
\hline 136 & 0,137 & 174 & 0,175 & 147 & 0,148 & 134 & 0,135 & 145 & 0,146 & 147 & 0,148 & 154 & 0,155 \\
\hline 341 & 0,342 & 289 & 0,290 & 345 & 0,346 & 334 & 0,335 & 338 & 0,339 & 307 & 0,308 & 306 & 0,307 \\
\hline 325 & 0,326 & 358 & 0,359 & 342 & 0,343 & 355 & 0,356 & 334 & 0,335 & 357 & 0,358 & 351 & 0,352 \\
\hline 177 & 0,178 & 165 & 0,166 & 150 & 0,151 & 157 & 0,158 & 169 & 0,170 & 179 & 0,180 & 175 & 0,176 \\
\hline
\end{tabular}

Table 3: Frequency and Percentage of answers from Public Service Quality (Y2)

\begin{tabular}{|c|c|c|c|c|c|c|c|c|c|c|c|c|c|}
\hline \multicolumn{2}{|c|}{ Y2.1.1 } & \multicolumn{2}{c|}{ Y2.2.1 } & \multicolumn{2}{c|}{ Y2.3.1 } & \multicolumn{2}{c|}{ Y2.4.1 } & \multicolumn{2}{c|}{ Y2.4.2 } & \multicolumn{2}{c|}{ Y243 } & \multicolumn{2}{c|}{ Y251 } \\
\hline $\mathbf{f}$ & $\%$ & $\mathbf{f}$ & \% & $\mathbf{f}$ & $\%$ & $\mathbf{f}$ & $\%$ & $\mathbf{f}$ & $\%$ & $\mathbf{f}$ & $\%$ & $\mathbf{f}$ & $\%$ \\
\hline 7 & 0,007 & 8 & 0,008 & 9 & 0,009 & 12 & 0,012 & 14 & 0,014 & 12 & 0,012 & 8 & 0,008 \\
\hline 172 & 0,173 & 162 & 0,163 & 161 & 0,162 & 163 & 0,164 & 146 & 0,147 & 157 & 0,158 & 155 & 0,156 \\
\hline 311 & 0,312 & 330 & 0,331 & 314 & 0,315 & 326 & 0,327 & 334 & 0,335 & 324 & 0,325 & 319 & 0,320 \\
\hline 354 & 0,355 & 318 & 0,319 & 365 & 0,366 & 318 & 0,319 & 329 & 0,330 & 337 & 0,338 & 344 & 0,345 \\
\hline 152 & 0,153 & 178 & 0,179 & 147 & 0,148 & 177 & 0,178 & 173 & 0,174 & 166 & 0,167 & 170 & 0,171 \\
\hline
\end{tabular}

\subsubsection{Public Service Quality (Y2)}

Public Service Quality (Y2) is measured by several indicators, namely Tangibles (Y2.1), Reliability (Y2.2), Responsiveness (Y2.3), Assurance (Y2.4) and Empathy (Y2.5). Tangibles (Y2.1), Reliability (Y2.2), Responsiveness (Y2.3) and Empathy (Y2.5) indicators are measured using one question item, while the Assurance (Y2.4) indicator is measured using three items question. In full, the frequency and percentage of Public Service Quality (Y2) answers can be seen in Table 3 .

\subsubsection{Public Empowerment (Y3)}

Public Empowerment (Y3) is measured by several items, namely Access to Information (Y3.1), Inclusion and Participation (Y3.2), Accountability (Y3.3) and Local Organizational Capacity (Y3.4). The Access to Information indicator (Y3.1) is measured using four question items, the Inclusion and Participation indicator (Y3.2) is measured using three question items, the Accountability indicator (Y3.3) is measured using one question item, while the Local Organizational Capacity (Y3 indicator) .4) measured using three question items. In full, the frequency and percentage of Public Empowerment (Y3) answers can be seen in Table 4. 
Table 4: Frequency and Percentage of answers from Public Empowerment (Y3)

\begin{tabular}{|c|c|c|c|c|c|c|c|c|c|c|c|c|c|}
\hline \multicolumn{2}{|c|}{ Y3.1.1 } & \multicolumn{2}{c|}{ Y3.1.2 } & \multicolumn{2}{c|}{ Y3.1.3 } & \multicolumn{2}{c|}{ Y3.1.4 } & \multicolumn{2}{|c|}{ Y3.2.1 } & \multicolumn{2}{c|}{ Y3.2.2 } & \multicolumn{2}{c|}{ Y3.2.3 } \\
\hline $\mathbf{f}$ & $\%$ & $\mathbf{f}$ & $\%$ & $\mathbf{f}$ & $\%$ & $\mathbf{f}$ & $\%$ & $\mathbf{f}$ & $\%$ & $\mathbf{f}$ & \% & $\mathbf{f}$ & $\%$ \\
\hline 8 & 0,008 & 13 & 0,013 & 13 & 0,013 & 14 & 0,014 & 12 & 0,012 & 12 & 0,012 & 10 & 0,010 \\
\hline 154 & 0,155 & 150 & 0,151 & 121 & 0,121 & 142 & 0,143 & 151 & 0,152 & 154 & 0,155 & 141 & 0,142 \\
\hline 310 & 0,311 & 321 & 0,322 & 318 & 0,319 & 336 & 0,337 & 307 & 0,308 & 315 & 0,316 & 349 & 0,350 \\
\hline 349 & 0,350 & 340 & 0,341 & 345 & 0,346 & 318 & 0,319 & 350 & 0,351 & 321 & 0,322 & 321 & 0,322 \\
\hline 175 & 0,176 & 172 & 0,173 & 199 & 0,200 & 186 & 0,187 & 176 & 0,177 & 194 & 0,195 & 175 & 0,176 \\
\hline
\end{tabular}

Table 4: (continuation)

\begin{tabular}{|c|c|c|c|c|c|c|c|}
\hline \multicolumn{2}{|c|}{ Y331 } & \multicolumn{2}{c|}{ Y341 } & \multicolumn{2}{c|}{ Y342 } & \multicolumn{2}{c|}{ Y343 } \\
\hline $\mathbf{f}$ & \% & $\mathbf{f}$ & $\mathbf{\%}$ & $\mathbf{f}$ & $\mathbf{\%}$ & $\mathbf{F}$ & \% \\
\hline 7 & 0,007 & 11 & 0,011 & 6 & 0,006 & 9 & 0,009 \\
\hline 150 & 0,151 & 172 & 0,173 & 149 & 0,150 & 146 & 0,147 \\
\hline 313 & 0,314 & 291 & 0,292 & 295 & 0,296 & 310 & 0,311 \\
\hline 349 & 0,350 & 341 & 0,342 & 358 & 0,359 & 347 & 0,348 \\
\hline 177 & 0,178 & 181 & 0,182 & 188 & 0,189 & 184 & 0,185 \\
\hline
\end{tabular}

Table 5: Model Fit

\begin{tabular}{|l|c|c|c|}
\hline Model Fit & $\begin{array}{c}\text { Statistic } \\
(\mathbf{P} \text { Value })\end{array}$ & Quality Indices & Decision \\
\hline Average path coefficient & APC $=0.265(\mathrm{P}<0.001)$ & Significant if $\mathrm{P}<=0.005$ & Significant \\
\hline Average R-squared & $\mathrm{ARS}=0.150(\mathrm{P}=0.001)$ & Significant ifP $<=0.005$ & Significant \\
\hline Average adjusted R-squared & $\mathrm{AARS}=0.146(\mathrm{P}=0.002)$ & Significant if $\mathrm{P}<=0.005$ & Significant \\
\hline Statistical suppression ratio & $\mathrm{SSR}=1$ & acceptable if $>=0.7$ & Acceptable \\
\hline Nonlinear bivariate causality direction ratio & $\mathrm{NLBCDR}=1$ & acceptable if $>=0.7$ & Acceptable \\
\hline
\end{tabular}

Table 6: Path Coefficients

\begin{tabular}{|c|c|c|c|c|}
\hline \multicolumn{2}{|c|}{ Relationship Between Variables } & Path Coefficient & P Value & Decision \\
\hline \multirow{2}{*}{$\mathrm{X}$} & $\mathrm{Y} 1$ & 0.404 & $<0.001$ & Significant \\
\cline { 2 - 5 } & $\mathrm{Y} 2$ & 0.169 & $<0.001$ & Significant \\
\hline \multirow{2}{*}{ Y1 } & $\mathrm{Y} 2$ & 0.294 & $<0.001$ & Significant \\
\cline { 2 - 5 } & $\mathrm{Y} 3$ & 0.206 & $<0.001$ & Significant \\
\hline Y2 & Y3 & 0.252 & $<0.001$ & Significant \\
\hline
\end{tabular}

\subsection{Model Fit}

The feasibility of the model can be demonstrated by several indicators. This study uses average path coefficient, average R-Squared, Average adjusted R-Squared, Statistical suppression ratio and nonlinear bivariate causality direction ratio. Table 5 shows the feasibility of the model from this study. The results in Table 5 are obtained using WarpPLS software. Based on Table 5 it can be concluded that the model is accepted as well as significant and feasible to use. This is indicated by significant APC, ARS and AARS values as well as acceptable SSR and NLBCDR values. 


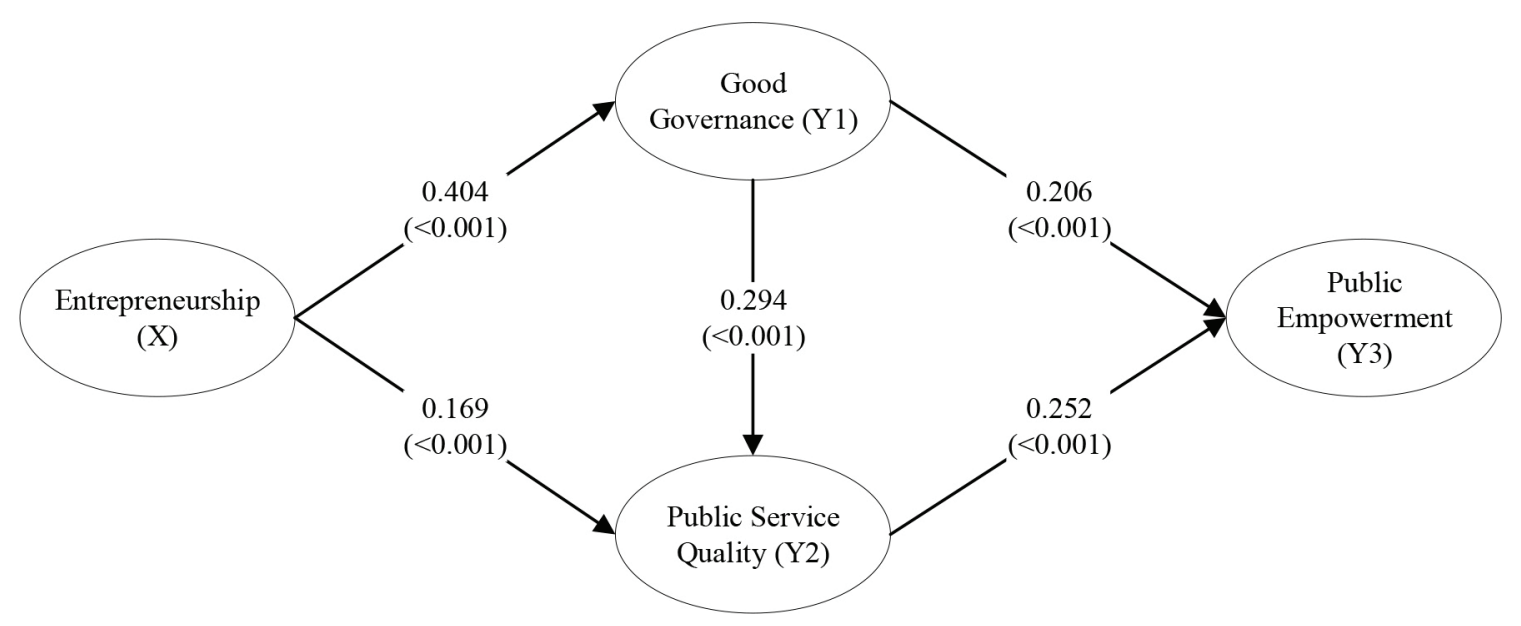

Figure 2: Path Coefficients

\subsection{Path Coefficient}

Based on Table 6 it can be seen that all relationships in the model have a p-value $<0.001$, so that at a significance level of $5 \%$ it can be concluded to have a significant effect. In addition, it can be seen that Entrepreneurship (X) has a positive and significant effect on Good Governance (Y1). Entrepreneurship (X) also has a positive and significant effect on Public Service Quality (Y2). Plus, Good Governance (Y1) has positive and significant effect on Public Service Quality (Y2) and Good Governance (Y1) also has positive and significant effect on Public Empowerment (Y3) and Public Service Quality (Y2) has positive and significant effect on Public Empowerment (Y3). Visually Path coefficients can be seen in Figure 2.

\section{Conclusion}

Based on the explanation above, it can be concluded that to improve Public Empowerment (Y3), local governments can improve good governance (Y1). In addition, Public Empowerment (Y3) can be improved by improving Public Service Quality (Y2). In addition, Good Governance (Y1) and Pubic Service Quality (Y2) are influenced by Entrepreneurship from the State Civil Apparatus (X), therefore the government needs to pay attention to Entrepreneurship from the State Civil Apparatus (X).

\section{References}

Bartlett, D., \& Dibben, P. (2002). Public sector innovation and entrepreneurship: Case studies from local government. Local Government Studies, 28(4), 107-121.

Chambers, R. (1995). Poverty and livelihoods: whose reality counts?. Environment and Urbanization, 7(1), 173-204.
Dwiyanto, A. (Ed.). (2005). Realizing good governance through public services. Yogyakarta, Indonesia: Gadjah Mada University Press.

Friedmann, J. (1992). Empowerment: The politics of alternative development. Oxford, UK: Blackwell.

Hardiyansyah. (2011). Quality of Public Services: Concept, Dimensions, Indicators and Implementation. Yogyakarta, Indonesia: Gava Media.

Hasan, B., Ulfah, A. K., Majid, \& M. S. A. (2017). The Implementation of Good Corporate Governance (GCG) to Improve Service Quality : The Case of State-Owned Electricity Company in Indonesia. Journal of Accounting, Finance and Auditing Studies, 3(2), 44-63.

Luc, P. T. (2018). The relationship between perceived access to finance and social entrepreneurship intentions among university students in Vietnam. Journal of Asian Finance, Economics and Business, 5(1), 63-72. http://dx.doi. org/10.13106/jafeb.2018.vol5.no1.63

Pranoto, A. R., \& Yusuf, D. (2014). Community EmpowermentBased CSR Program Towards Post-Mining Economic Independence in Sarijaya Village. Jurnal Ilmu Sosial dan Ilmu Politik, 18(1), 39-50.

Sadler, R. J. (2000). Corporate entrepreneurship in the public sector: the dance of the chameleon. Australian Journal of Public Administration, 59(2), 25-43.

Samiun, B., Sjahruddin, H., \& Purnomo, S. H. (2017). The Effect of Empowerment on Employee Job Satisfaction. Jakarta, Indonesia: Salemba Empat.

Slevin, D. P., \& Covin, J. G. (1990). Juggling entrepreneurial style and organizational structure. Sloan Management Review, 31(2), 43-53.

Somasundram, S., Sirag, A., Rasiah, R., \& Habibullah, M. S. (2017). Religious Oppression: Government Regulations and Social Hostilities. Journal of Asian Finance, Economics 
and Business, 4(4), 39-49. http://dx.doi.org/10.13106/ jafeb.2017.vol4.no4.39

Suryana, D., \& Si, M. (2006). Entrepreneurship: Practical Guidelines (Tips and processes for success). Jakarta, Indonesia: Salemba Empat.

Susanto, D., Yusuf, A. D., \& Rachmawati, Y. (2015). The Effect of Good Governance on the Quality of Public Service Delivery. Jurnal Paradigma, 12(2), 73-91.
Wirasari, N. (2010). Public Improvement through Empowerment of Beji Village Apparatus, East Ungaran District in Archives Management. Rekayasa, 8(2). [Indonesia]

Yi, H. T., Han, C. N., \& Cha, Y. B. (2018). The Effect of Entrepreneurship of SMEs on Corporate Capabilities, Dynamic Capability and Technical Performances in South Korea. Journal of Asian Finance, Economics and Business, 5(4), 135147. http://doi.org/10.13106/jafeb.2018.vol5.no4.135 